\title{
Large-scale Experimental Validation of a Model for the Kinetics of Ozone and Hydroxyl Radicals with Natural Organic Matter
}

\author{
Pierre Mandel, ${ }^{* \dagger}$ Pascal Roche, ${ }^{\dagger}$ and Dominique Wolbert ${ }^{\star}$
}

Veolia Environnement Recherche \& Innovation, Chemin de la digue, BP 76, 78603 Maisons-Laffitte, France,

Ecole Nationale Supérieure de Chimie de Rennes, CNRS UMR 6226, Avenue du Général Leclerc, CS 5083735708 Rennes Cedex 7, France

*Corresponding author e-mail: pierre.mandel@veolia.com,

${ }^{\dagger}$ Veolia Environnement Research \& Innovation,

${ }^{\ddagger}$ Ecole Nationale de Chimie de Rennes.

\begin{abstract}
A unified model for the kinetics of $\mathrm{O}_{3}$ and ${ }^{\circ} \mathrm{OH}$ with $\mathrm{NOM}$ was proposed, calibrated and validated based on large experimental datasets. Single phase batch experiments were done on 11 water samples from 7 resources. Seasonal variations were studied on 3 resources. Effects of reaction time with ozone, ozone dose, $\mathrm{pH}$, temperature, radical scavenger adding, NOM dilution were studied. The experiments represented more than 1200 and 900 concentration measurements, respectively for ozone and $p$ CBA ( ${ }^{\circ} \mathrm{OH}$ tracer). Mechanistic models were used for ozone self-decomposition and carbonate species kinetics. Results showed that the proposed model is robust and can handle different water characteristics and different experimental conditions: $75 \%$ of the experiments were modeled satisfactorily (for ozone and $p \mathrm{CBA}$ ). Following domain of validity was determined: $6 \leq \mathrm{pH} \leq 8 ; 1$ meq. $\mathrm{L}^{-1} \leq$ alkalinity $\leq 6$ meq. $\mathrm{L}^{-1} ; 0-0.5 \mathrm{mgC} . \mathrm{L}^{-1} \leq \mathrm{TOC} \leq 3.1 \mathrm{mgC} . \mathrm{L}^{-1}$. Only water samples with high organic (TOC $>2.4 \mathrm{mg} . \mathrm{L}^{-1}$ ) and low inorganic contents (alkalinity $<0.3 \mathrm{meq} . \mathrm{L}^{-1}$ ) could not be modeled adequately. Seasonal comparisons showed that the quality of the predictions decreases only for $p$ CBA when having calibrated the model at another season. The model gave good results when using only 6 single batch experiments for calibration.
\end{abstract}

KEYWORDS. Ozone Decomposition, Natural Organic Matter, Kinetics, Drinking Water Treatment, Bromate, Model Calibration, Process Simulation; Micropollutants.

\section{HIGHLIGHTS.}

- A reaction mechanism for $\mathrm{O}_{3}$ and ${ }^{\circ} \mathrm{OH}$ with $\mathrm{NOM}$ is proposed, calibrated, and validated

- More than 2100 concentration measurements were used to validate the model

- $75 \%$ of the experiments were modeled satisfactorily, for $\mathrm{O}_{3}$ and ${ }^{\circ} \mathrm{OH}$

- Validity domain: $6 \leq \mathrm{pH} \leq 8 ; 1 \leq$ alkalinity $\leq 6$ meq.L $\mathrm{L}^{-1} ; 0-0.5 \leq \mathrm{TOC} \leq 3.1 \mathrm{mgC} \cdot \mathrm{L}^{-1}$

- The model for ozone is robust against seasonal variations in NOM

\author{
ABBREVIATIONS. \\ $\mathrm{A}_{\mathrm{T}}$ : Alkalinity \\ NOM: Natural Organic Matter \\ pCBA: Para ChloroBenzoic Acid \\ SUVA: Specific UltraViolet Absorbance \\ TOC: Total Organic Carbon
}




\section{INTRODUCTION}

Assisted by modeling tools, management of ozonation processes shall comply with conflicting standards on disinfection and by-products (bromate ions) [1], also taking into account emerging micropollutants. Recently, legal and environmental contexts indeed became more constraining: (i) in many countries, regulations on bromate have dropped to $10 \mu \mathrm{g} . \mathrm{L}^{-1}$ [2]; (ii) micropollutants are being increasingly detected in the environment [3].

While the chemistry of ozone is relatively well understood - and hence modeled - in synthetic water; in natural water, however, chemical phenomena are more difficult to study. Particularly, Natural Organic Matter (NOM), generally described as a poorly defined mix of organic substances [4], may react in different ways with ozone and hydroxyl radicals [5]. Also, NOM's composition is influenced by seasonal variations and particulate organic carbon inputs [6]. Finally, quantifying the concentrations of the many ozone-consuming sites in NOM remains difficult, as well as linking reaction kinetics of NOM with measurable physical data [7]. Consequently, there is a need to develop and evaluate unified kinetics models for NOM on the basis of large experimental datasets.

Several studies have already proposed or used models for the kinetics of ozone in natural water, but their results need to be extended, both experimentally and numerically. The simplest approach consists in postulating a pseudo-first order kinetic law for ozone decomposition (see e.g. [8] for a review). Some authors consider a two-steps decomposition of ozone, with laws of different orders; for instance, zeroorder ("Instantaneous Ozone Demand") followed by first-order decompositions, e.g. [9]. When hydroxyl radicals are sought to be modeled, it is of convenience to use the $\mathrm{R}_{\mathrm{ct}}$ concept [10] in order to recalculate hydroxyl radical concentration based on ozone concentration. This has been done to model: bromate and cryptosporidium fates in a pilot [11]; micropollutants removal in a full-scale wastewater ozonation unit [12]. Values for the $\mathrm{R}_{\mathrm{ct}}$ are highly dependent on water characteristics and on NOM [13], but a recent study proposed an empirical calculation of the $\mathrm{R}_{\mathrm{ct}}[14]$. For more detailed descriptions of the chemistry of ozone, authors use reaction mechanisms. Westerhoff and coworkers [16] focused on the prediction of bromate formation, while Acero and von Gunten [17] focused on the impact of hydrogenocarbonate concentration. Both teams worked with NOM isolates from water samples. Only Bezbarua [15], based on a large experimental dataset, focused on the kinetics of ozone with NOM. A natural pond water sample was fractionated according to the method of Leenheer and Noyes [18] and the kinetics of each fraction was studied. However, predicting simultaneously ozone and hydroxyl radical concentrations remains no easy task [7], and previous studies need to be extended: experimentally, a limited number of water samples were studied; numerically, critical issues on model analysis were rarely discussed: domain of validity (including seasonal variations of NOM), model calibration, model validation.

The objective of this article is to study and validate a unified model for the kinetics of NOM with ozone and hydroxyl radicals based on a large experimental dataset. Special attention has been given to (i) define the domain of validity of the model (water characteristics, experimental conditions and seasonal variations of NOM); (ii) propose a small number of experiments for model calibration; and (iii) statistically evaluate the model's performance.

Since ozone and hydroxyl radicals are the two main oxidative species of ozonation processes, their concentrations have to be precisely measured and modeled before calculating disinfection, simulating the fate of micropollutants or the formation of bromate ions. The model was first evaluated statistically and its domain of validity determined using all experimental data for calibration. Robustness of the model against seasonal variations of NOM and experimental conditions was then studied and statistically assessed by calibrating the model only with a limited number of experiments. 


\section{MATERIALS AND METHODS}

\subsection{Experimental}

The single-phase protocol presented in [19] was used in this study (including analyses). A $100 \mathrm{~mL}$ gastight syringe was used as reactor. Ozonized ultrapure water was injected through a sampling septum; volumes ranged from $3 \mathrm{~mL}$ to $5 \mathrm{~mL}$. An oval stirring bar was used to achieve perfect stirring conditions. Throughout the experiment, samples $(2 \mathrm{~mL}$ to $5 \mathrm{~mL})$ were withdrawn for analysis. Two concentrations were followed during every experiment: ozone and para chlorobenzoic acid ( $p$ CBA, used as hydroxyl radical probe compound as in e.g. [20]).

The water samples were chosen in order to cover a wide domain of experimental conditions: $\mathrm{pH}$, alkalinity $\left(\mathrm{A}_{\mathrm{T}}\right)$ and Total Organic Carbon (TOC). Additionally, various types of natural water were investigated, taken from wells, from three different rivers and from dams or lakes. Each water sample was collected just before the ozonation unit at the corresponding local plant. Moreover, specific water resources were collected at different periods of the year to assess the effect of seasonal changes (Annetsur-Marne, Meulan and Vitré). Details on the water samples are summarized in table 1.

The same experimental conditions as those presented in [19] were investigated in this study: reaction time with ozone, ozone dose, $\mathrm{pH}$, temperature, presence of radical scavengers (10 $\mathrm{mM}$ tert-butanol), NOM dilution (for every water sample, the NOM concentration was varied by diluting the water sample with ultra pure water, ozonized and deozonized beforehand). Experiments were done according to three successive designs of experiments: a two-level full-factorial approach tested with \{Méry-sur-Oise, Fall \} and \{Maisons-Laffitte, Winter\} was later simplified (see [21]). The difference between low and high experimental temperatures was set at $5.5^{\circ} \mathrm{C}$ for the first design of experiments, then increased to circa $15^{\circ} \mathrm{C}$. In total, the dataset represented more than 1200 and 900 concentration measurements, respectively for ozone and $p \mathrm{CBA}$, see table 1 .

Table 1. Main characteristics of the water samples investigated and number of measurements (designs of experiments are separated by double horizontal lines)

\begin{tabular}{|c|c|c|c|c|c|c|c|c|}
\hline $\begin{array}{l}\text { Water sample } \\
\text { Water origin }\end{array}$ & & $\mathrm{pH}$ & $\begin{array}{l}\mathrm{A}_{\mathrm{T}} \\
\text { meq. } \mathrm{L}^{-1}\end{array}$ & $\begin{array}{l}\text { TOC } \\
\text { mg C.L } \mathrm{L}^{-1}\end{array}$ & $\begin{array}{l}\text { SUVA } \\
\text { L.mgC }{ }^{-1} \cdot \mathrm{m}^{-1}\end{array}$ & $\begin{array}{l}\text { Number of } \\
\text { experiments }\end{array}$ & $\begin{array}{l}\text { Num } \\
\text { mea } \\
\mathrm{O}_{3} \\
\end{array}$ & $\begin{array}{l}r \text { of } \\
\text { ements } \\
p \text { CBA } \\
\end{array}$ \\
\hline $\begin{array}{l}\text { Méry-sur-Oise, Fall } \\
\text { Sand filtered surface water }\end{array}$ & (Nov. 2008) & 7.85 & 4.55 & 3.1 & 1.06 & 32 & 224 & 224 \\
\hline $\begin{array}{l}\text { Maisons-Laffitte, Winter } \\
\text { Artesian well }\end{array}$ & (Dec. 2008) & 8.15 & 2.40 & $<0.5$ & - & 32 & 224 & 224 \\
\hline $\begin{array}{l}\text { Vitré, Winter } \\
\text { Sand filtered dam water }\end{array}$ & (Feb. 2009) & 7.40 & 1.02 & 2.0 & 1.3 & 14 & 98 & 56 \\
\hline $\begin{array}{l}\text { Annet-sur-Marne, Winter } \\
\text { Sand filtered surface water }\end{array}$ & (Feb. 2009) & 7.40 & 2.82 & 1.3 & 1.43 & 14 & 98 & 56 \\
\hline $\begin{array}{l}\text { Meulan, Spring } \\
\text { Bank filtered surface water }\end{array}$ & (Mar. 2009) & 7.25 & 6.24 & 0.9 & 2.02 & 14 & 98 & 56 \\
\hline $\begin{array}{l}\text { Beaufort, Spring } \\
\text { Sand filtered dam water }\end{array}$ & (Mar. 2009) & 6.05 & 0.12 & 2.4 & 1.18 & 14 & 98 & 56 \\
\hline $\begin{array}{l}\text { Trondheim, Spring } \\
\text { Sand filtered Jontsvatnet Lak }\end{array}$ & $\begin{array}{l}\text { (Mar. 2009) } \\
\text { water }\end{array}$ & 7.35 & 0.32 & 3.1 & 0.66 & 14 & 98 & 56 \\
\hline Annet-sur-Marne, Summer & (July 2009) & 8.05 & 4.24 & 1.6 & 1.03 & 10 & 70 & 49 \\
\hline Annet-sur-Marne, Fall & (Oct. 2009) & 7.70 & 3.08 & 1.6 & 1.23 & 10 & 70 & 49 \\
\hline Meulan, Fall & (Nov. 2009) & 7.30 & 6.02 & 1.3 & 1.35 & 10 & 70 & 49 \\
\hline Vitré, Fall & (Nov. 2009) & 7.10 & 1.24 & 2.3 & 1.03 & 10 & 70 & 49 \\
\hline
\end{tabular}




\subsection{Kinetics Models}

\subsubsection{Ozone Self-Decomposition}

The mechanism used for ozone self-decomposition derives from that presented in [22]. The mechanism used in this study is presented in table 2 .

Table 2. Mechanism for ozone self-decomposition

\begin{tabular}{|c|c|c|c|c|}
\hline Type & Reaction & \multicolumn{2}{|c|}{$\begin{array}{l}\text { Kinetic constant value } \\
(\mathrm{T}=293 \mathrm{~K})\end{array}$} & Reference \\
\hline \multirow[t]{2}{*}{ Initiation } & $\mathrm{O}_{3}+\mathrm{HO}^{-} \rightarrow \mathrm{HO}_{2}^{-}+\mathrm{O}_{2}$ & \multicolumn{2}{|c|}{$4.10^{1} \mathrm{M}^{-1} \cdot \mathrm{s}^{-1}$} & {$[23]$} \\
\hline & $\mathrm{HO}_{2}^{-}+\mathrm{O}_{3} \rightarrow^{\bullet} \mathrm{OH}+{ }^{\bullet} \mathrm{O}_{2}^{-}+\mathrm{O}_{2}$ & \multicolumn{2}{|l|}{$2.8 .10^{6} \mathrm{M}^{-1} . \mathrm{s}^{-1}$} & {$[24]$} \\
\hline \multirow[t]{5}{*}{ Propagation } & $O_{3}+O_{2}^{-} \rightarrow^{\bullet} O_{3}^{-}+O_{2}$ & \multicolumn{2}{|l|}{$1.6 .10^{9} \mathrm{M}^{-1} \cdot \mathrm{s}^{-1}$} & {$[25]$} \\
\hline & $\mathrm{HO}_{3} \rightarrow{ }^{\bullet} \mathrm{OH}+\mathrm{O}_{2}$ & \multicolumn{2}{|l|}{$1.1 .10^{5} \mathrm{~s}^{-1}$} & [26] \\
\hline & $\cdot \mathrm{OH}+\mathrm{O}_{3} \rightarrow \mathrm{HO}_{2}+\mathrm{O}_{2}$ & \multicolumn{2}{|l|}{$9.10^{5} \mathrm{M}^{-1} \cdot \mathrm{s}^{-1}$} & {$[22]$} \\
\hline & $\cdot \mathrm{OH}+\mathrm{H}_{2} \mathrm{O}_{2} \rightarrow{ }^{\bullet} \mathrm{HO}_{2}+\mathrm{H}_{2} \mathrm{O}$ & \multicolumn{2}{|l|}{$2.7 .10^{7} \mathrm{M}^{-1} . \mathrm{s}^{-1}$} & [27] \\
\hline & ${ }^{\bullet} \mathrm{OH}+\mathrm{HO}_{2}^{-} \rightarrow \mathrm{O}_{2}^{-}+\mathrm{H}_{2} \mathrm{O}$ & \multicolumn{2}{|l|}{$7.5 .10^{9} \mathrm{M}^{-1} . \mathrm{s}^{-1}$} & {$[27]$} \\
\hline \multirow[t]{5}{*}{ Termination } & $2^{\circ} \mathrm{OH} \rightarrow \mathrm{H}_{2} \mathrm{O}_{2}$ & \multicolumn{2}{|l|}{$5.10^{9} \mathrm{M}^{-1} \cdot \mathrm{s}^{-1}$} & [28] \\
\hline & $\cdot \mathrm{OH}+{ }^{\bullet} \mathrm{O}_{2}^{-} \rightarrow \mathrm{HO}^{-}+\mathrm{O}_{2}$ & \multicolumn{2}{|l|}{$10^{10} \mathrm{M}^{-1} \cdot \mathrm{s}^{-1}$} & {$[28]$} \\
\hline & ${ }^{\circ} \mathrm{OH}+{ }^{\bullet} \mathrm{HO}_{3} \rightarrow \mathrm{H}_{2} \mathrm{O}_{2}+\mathrm{O}_{2}$ & \multicolumn{2}{|l|}{$5.10^{9} \mathrm{M}^{-1} \cdot \mathrm{s}^{-1}$} & [29] \\
\hline & ${ }^{\bullet} \mathrm{HO}_{3}+{ }^{\bullet} \mathrm{O}_{2}^{-} \rightarrow \mathrm{HO}^{-}+2 \mathrm{O}_{2}$ & \multicolumn{2}{|l|}{$10^{10} \mathrm{M}^{-1} \cdot \mathrm{s}^{-1}$} & [29] \\
\hline & $2^{\bullet} \mathrm{HO}_{3} \rightarrow \mathrm{H}_{2} \mathrm{O}_{2}+2 \mathrm{O}_{2}$ & \multicolumn{2}{|l|}{$5.10^{9} \mathrm{M}^{-1} \cdot \mathrm{s}^{-1}$} & [29] \\
\hline \multicolumn{2}{|l|}{$\begin{array}{l}\text { Acid-base } \\
\text { equilibria }\end{array}$} & \multicolumn{3}{|c|}{ Dive } \\
\hline $\mathrm{pK}_{\mathrm{A}}=8.2$ & $\mathrm{O}_{3}^{-}+\mathrm{H}^{+} \leftrightarrow{ }^{\bullet} \mathrm{HO}_{3}$ & $5.2 .10^{10} \mathrm{M}^{-1} \cdot \mathrm{s}^{-1}$ & $3.3 .10^{2} \mathrm{~s}^{-1}$ & [26] \\
\hline $\mathrm{pK}_{\mathrm{A}}=4.8$ & $\mathrm{O}_{2}^{-}+\mathrm{H}^{+} \leftrightarrow{ }^{\bullet} \mathrm{HO}_{2}$ & $2.10^{10} \mathrm{M}^{-1} \cdot \mathrm{s}^{-1}$ & $3.2 .10^{5} \mathrm{~s}^{-1}$ & {$[30]$} \\
\hline $\mathrm{pK}_{\mathrm{A}}=11.6$ & $\mathrm{HO}_{2}^{-}+\mathrm{H}^{+} \leftrightarrow \mathrm{H}_{2} \mathrm{O}_{2}$ & $10^{10} \mathrm{M}^{-1} \cdot \mathrm{s}^{-1}$ & $4.2 .10^{-2} \mathrm{~s}^{-1}$ & {$[30]$} \\
\hline
\end{tabular}

\subsubsection{Influence of Carbonate Species}

Most reactions used to model the role played by carbonate species (i.e. inorganic carbon) were taken from [16]. Despite the high value of the $\mathrm{pK}_{\mathrm{A}}$ of carbonate radicals, the initiation reaction producing a hydrogenocarbonate radical was neglected due to the minor role of the hydrogenocarbonate radical in radical scavenging. The complete mechanism is presented in table 3 . The kinetics of the deprotonation reactions were calculated based on the $\mathrm{pK}_{\mathrm{A}}$ values and on the kinetics of the protonation reactions.

Table 3. Mechanism for the influence of carbonate species

Type

Reaction

Kinetic constant value

Reference

$(293 \mathrm{~K})$

\begin{tabular}{llll}
\hline Initiation & $\mathrm{CO}_{3}^{2-}+{ }^{\bullet} \mathrm{OH} \rightarrow{ }^{\bullet} \mathrm{CO}_{3}^{-}+\mathrm{HO}^{-}$ & $3.9 .10^{8} \mathrm{M}^{-1} \cdot \mathrm{s}^{-1}$ & {$[30]$} \\
\cline { 2 - 4 } & $\mathrm{HCO}_{3}^{-}+{ }^{\bullet} \mathrm{OH} \rightarrow{ }^{\bullet} \mathrm{CO}_{3}^{-}+\mathrm{H}_{2} \mathrm{O}$ & $5.10^{7} \mathrm{M}^{-1} \cdot \mathrm{s}^{-1}$ & {$[28]$} \\
\hline Propagation & ${ }^{\circ} \mathrm{CO}_{3}^{-}+\mathrm{HO}_{2}^{-} \rightarrow \mathrm{CO}_{3}^{2-}+{ }^{\bullet} \mathrm{HO}_{2}$ & $5.6 .10^{7} \mathrm{M}^{-1} \cdot \mathrm{s}^{-1}$ & {$[16]$} \\
\hline
\end{tabular}




\begin{tabular}{|c|c|c|c|c|}
\hline & ${ }^{\bullet} \mathrm{CO}_{3}^{-}+\mathrm{H}_{2} \mathrm{O}_{2} \rightarrow \mathrm{HCO}_{3}^{-}+{ }^{\bullet} \mathrm{HO}_{2}$ & $8.10^{5} \mathrm{M}^{-1} \cdot \mathrm{s}^{-1}$ & & [28] \\
\hline \multirow[t]{3}{*}{ Termination } & ${ }^{\cdot} \mathrm{CO}_{3}^{-}+{ }^{\bullet} \mathrm{O}_{2}^{-} \rightarrow \mathrm{CO}_{3}^{2-}+\mathrm{O}_{2}$ & $4.10^{8} \mathrm{M}^{-1} \cdot \mathrm{s}^{-1}$ & & [16] \\
\hline & ${ }^{\cdot} \mathrm{CO}_{3}^{-}+{ }^{\bullet} \mathrm{O}_{3}^{-} \rightarrow \mathrm{CO}_{3}^{2-}+\mathrm{O}_{3}$ & $6.10^{7} \mathrm{M}^{-1} \cdot \mathrm{s}^{-1}$ & & [31] \\
\hline & ${ }^{\bullet} \mathrm{CO}_{3}^{-}+{ }^{\bullet} \mathrm{OH} \rightarrow \mathrm{CO}_{2}+\mathrm{HO}_{2}^{-}$ & $3.10^{9} \mathrm{M}^{-1} \cdot \mathrm{s}^{-1}$ & & [16] \\
\hline $\begin{array}{l}\text { Acid-base } \\
\text { equilibria }\end{array}$ & & Direct & Reverse & \\
\hline $\mathrm{pK}_{\mathrm{A}}=10.3$ & $\mathrm{CO}_{3}^{2-}+\mathrm{H}^{+} \leftrightarrow \mathrm{HCO}_{3}^{-}$ & $5.10^{10} \mathrm{M}^{-1} \cdot \mathrm{s}^{-1}$ & $2.5 \mathrm{~s}^{-1}$ & [32] \\
\hline $\mathrm{pK}_{\mathrm{A}}=9.6$ & ${ }^{\cdot} \mathrm{CO}_{3}^{-}+\mathrm{H}^{+} \leftrightarrow{ }^{\bullet} \mathrm{HCO}_{3}$ & $5.10^{10} \mathrm{M}^{-1} \cdot \mathrm{s}^{-1}$ & $1.26 .10^{1} \mathrm{~s}^{-1}$ & [33] \\
\hline $\mathrm{pK}_{\mathrm{A}}=6.4$ & $\mathrm{HCO}_{3}^{-}+\mathrm{H}^{+} \leftrightarrow \mathrm{H}_{2} \mathrm{CO}_{3}$ & $5.10^{10} \mathrm{M}^{-1} \cdot \mathrm{s}^{-1}$ & $2.10^{4} \mathrm{~s}^{-1}$ & [32] \\
\hline
\end{tabular}

\subsubsection{Influence of NOM}

The model for the kinetics of NOM with ozone and hydroxyl radicals (called "model" in the following) used in this study is detailed in [19] and [21]. Reactive NOM was divided into three fractions (consumers, initiators and promoters) and six species (two for each fraction: an acid and its conjugate base). The reactions of NOM are summarized in table 4. In order to describe the acid character of the NOM fractions, a $\mathrm{pK}_{\mathrm{A}}$ was defined for each fraction. The initial concentration and reactivity of each species $\left(N O M^{d}{ }_{a}, N O M_{b}^{d}, N O M_{a}^{i}, N O M_{b}^{i}, N O M^{p}{ }_{a}\right.$ and $\left.N O M^{p}{ }_{b}\right)$ had to be calibrated. Because many organic compounds have $\mathrm{pH}$-dependent kinetics in their reactions with ozone (e.g. formic and glycoxylic acids [5], phenolic groups [34]...), one of the species of each fraction was considered having a negligible reactivity. Moreover, temperature effects were modeled through the calibration of energies of activation. In the end, 12 model parameters had to be adjusted to fit simulations to experimental data: 3 initial concentrations, 3 kinetic constants, $3 \mathrm{pK}_{\mathrm{A}}$ and 3 energies of activation.

Table 4. Reactions with organic matter

\begin{tabular}{ll} 
Type (NOM fraction) & Reaction \\
\hline Direct consumption (consumers) & $\mathrm{NOM}^{d}+\mathrm{O}_{3} \rightarrow$ products \\
\hline Chain initiation (initiators) & $\mathrm{NOM}^{i}+\mathrm{O}_{3} \rightarrow^{\bullet} \mathrm{OH}+$ products \\
\hline Chain promotion (promoters) & $\mathrm{NOM}^{p}+{ }^{\bullet} \mathrm{OH} \rightarrow{ }^{\bullet} \mathrm{O}_{2}^{-}+$products $^{d, i, p}$ \\
\hline \hline Acid-base equilibrium & $\mathrm{NOM}_{a}^{d, i, p} \stackrel{\mathrm{K}_{\mathrm{d}, i, p}}{\longrightarrow} \mathrm{NOM}_{b}^{d, i, p}+H^{+}$
\end{tabular}

\subsection{Modeling Procedure}

The concentrations of all chemical species involved in the kinetic models were calculated by solving mass balances. The gas-tight syringe was modeled as a perfectly stirred reactor; accordingly, the mass balance resulted in a large set of non-linear ordinary differential equations. An initial concentration was given to every chemical species; radicals were mostly given a default $10^{-10} \mu \mathrm{M}$ concentration (detailed values shall be found in [21]).

\subsection{Statistical Interpretation of the Results}

Goodness-of-fit was measured following the recommendations of [35]: a combination of the value of the objective function $O_{f}$ (see equation 1) and of the coefficient of determination $R^{2}$ was used. Handling experimental data with different orders of magnitude, the values for $p \mathrm{CBA}$ concentrations were weighted before calculating $R^{2}$. 
$O_{f}=\sum_{i=1}^{n}\left(\frac{Y_{\mathrm{exp}, i}-Y_{\text {sim }, i}}{Y_{\mathrm{exp}, i} \cdot s_{\mathrm{exp}, i}}\right)^{2}$

Where:

- $\quad n$ is the number of concentration measurements for a given water sample

- $\quad Y_{\text {exp }, i}$ is the $i^{\text {th }}$ concentration measurement

- $\quad Y_{\text {sim, } i}$ is the $i^{\text {th }}$ concentration simulation (issued from the model)

- $\quad s_{\text {exp }, i}$ is the experimental standard deviation of the $i^{\text {th }}$ concentration measurement

Three groups of experiments were defined:

- $\quad$ very good experiments, for which $R^{2}>0.7$ and $O_{f}<1.5$;

- $\quad$ good experiments, for which $\left\{R^{2}>0.7\right.$ and $\left.O_{f} \geq 1.5\right\}$ or $\left\{R^{2} \leq 0.7\right.$ and $\left.O_{f}<1.5\right\}$;

- $\quad$ mediocre or bad experiments, in any other cases.

The boundary of 0.7 for $R^{2}$ was determined qualitatively. The value of 1.5 for $O_{f}$ was determined statistically. 1.5 is the approximate median value of an empirical cumulative distribution function built with 5000 acceptable (i.e. equal to experimental values \pm experimental error) data sets of simulated concentrations created randomly [21].

\section{RESULTS}

In order to evaluate the model and determine its domain of validity, all the experiments of each water sample were used for model calibration. We show in figures 1 to 5 how the model is able to take into account experimental condition changes: reaction time with ozone, ozone dose, $\mathrm{pH}$, temperature, radical formation potential (with or without radical scavengers) and NOM dilution. Different water samples have been systematically chosen in order to give the best overview of the model's abilities. The global experimental uncertainties, determined with experiment replicates done with Méry-sur-Oise, Fall $\}$ and \{Maisons-Laffitte, Winter \} water samples are following: $\pm 0.1 \mathrm{mg} . \mathrm{L}^{-1}$ for ozone and $\pm 4 \mu \mathrm{g} . \mathrm{L}^{-1}$ for $p$ CBA.
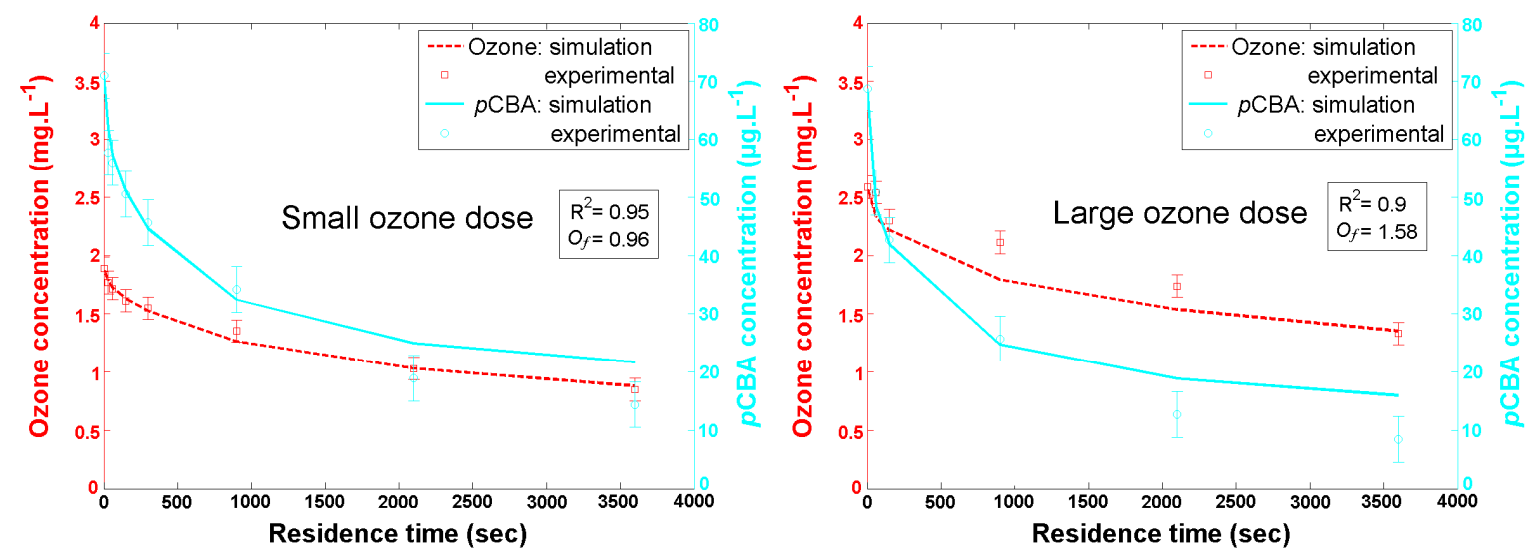

Figure 1. Experimental and simulated concentration profiles, $\{$ Maisons-Laffitte, Winter $\}$ water: $A_{T}=2.4$ meq. $\mathrm{L}^{-1}$; natural $\mathrm{pH}=8.15 ; \mathrm{T}=13.5^{\circ} \mathrm{C}$; no radical scavenger adding; $\mathrm{TOC}<0.5 \mathrm{mg} . \mathrm{L}^{-1}$; left: small ozone dose $=1.9 \mathrm{mg} . \mathrm{L}^{-1}$, right: large ozone dose $=2.6 \mathrm{mg} . \mathrm{L}^{-1}$ 

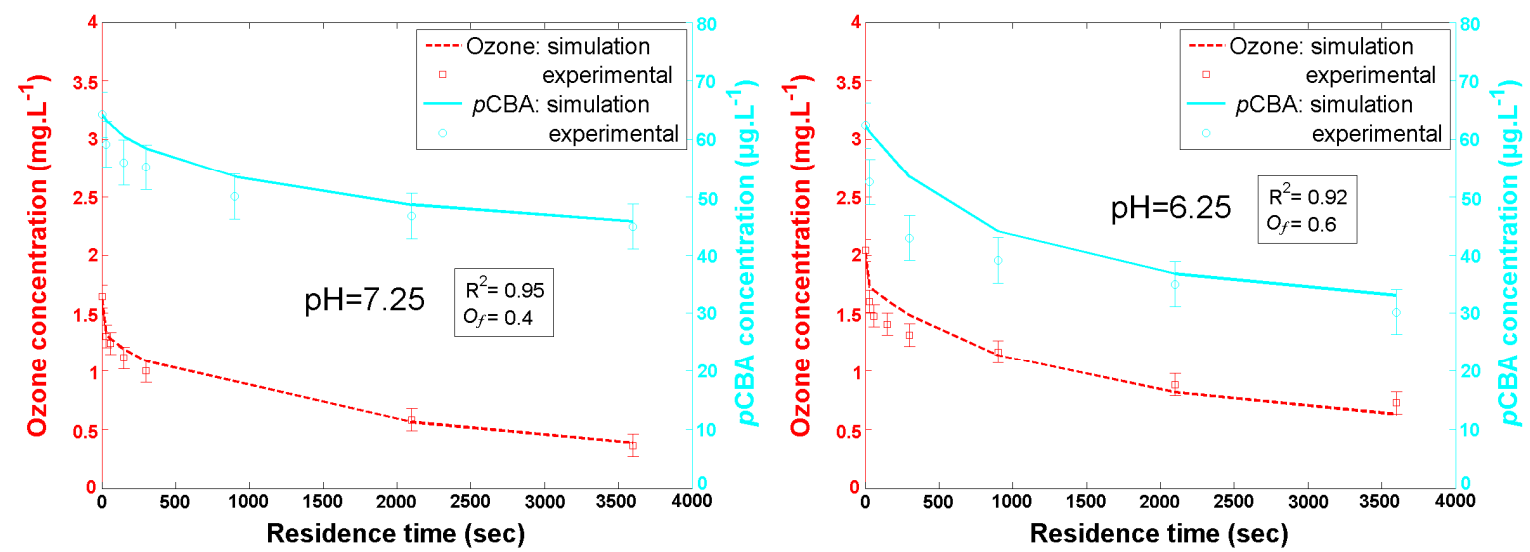

Figure 2. Experimental and simulated concentration profiles, $\{$ Meulan, Spring $\}$ water: $A_{T}=6.24$ meq. $\mathrm{L}^{-}$ ; small ozone dose $\approx 1.9 \mathrm{mg} . \mathrm{L}^{-1}$; $\mathrm{T}=20^{\circ} \mathrm{C}$; no radical scavenger adding; $\mathrm{TOC}=0.9 \mathrm{mg} . \mathrm{L}^{-1}$; left: $\mathrm{pH}=7.25$, right: $\mathrm{pH}=6.25$
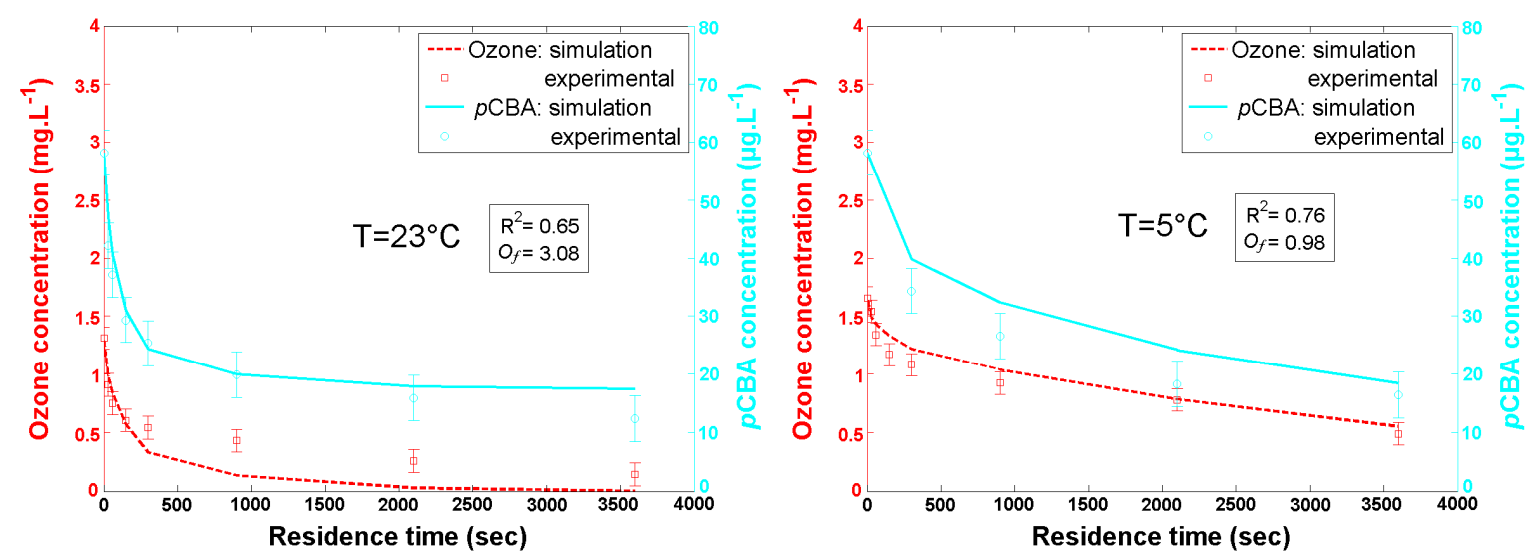

Figure 3. Experimental and simulated concentration profiles, \{ Annet-sur-Marne, Fall $\}$ water: $A_{T}=3.08$ meq. $\mathrm{L}^{-1}$; small ozone dose $\approx 1.5 \mathrm{mg} . \mathrm{L}^{-1} ; \mathrm{pH}=7.7$; no radical scavenger adding; $\mathrm{TOC}=1.6 \mathrm{mg} . \mathrm{L}^{-1}$; left: $\mathrm{T}=23^{\circ} \mathrm{C}$, right: $\mathrm{T}=5^{\circ} \mathrm{C}$
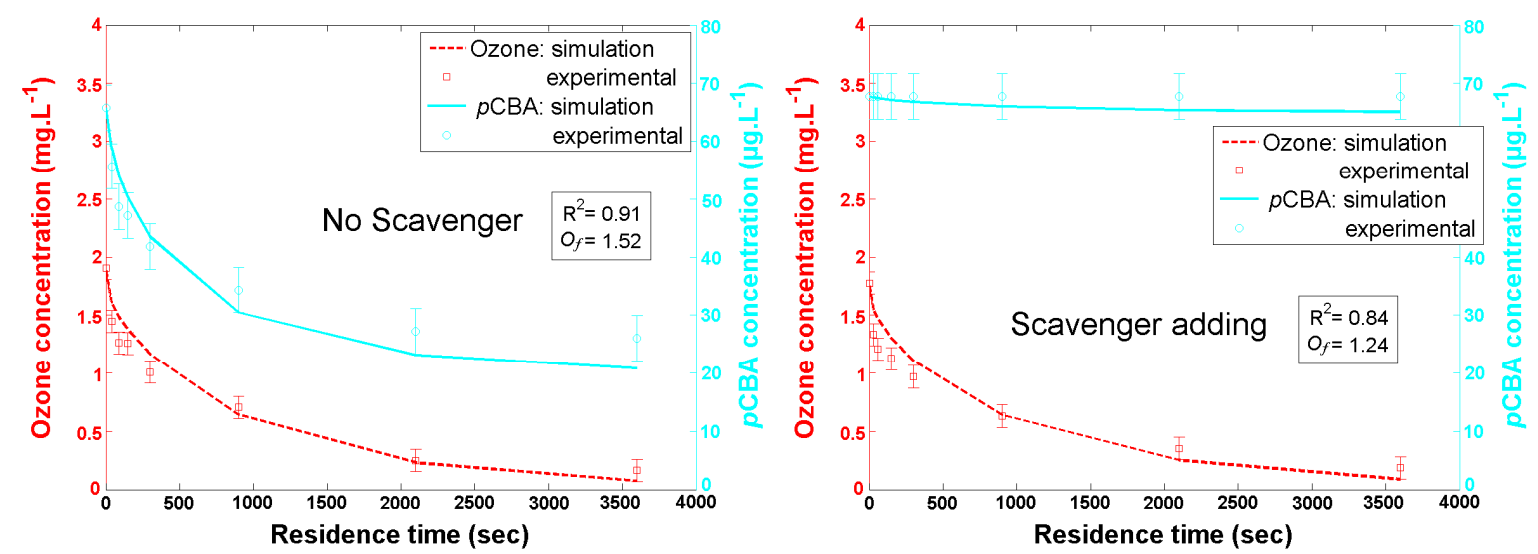

Figure 4. Experimental and simulated concentration profiles, $\{$ Méry-sur-Oise, Fall $\}$ water: $A_{T}=4.55$ meq. $\mathrm{L}^{-1}$; small ozone dose $\approx 1.9 \mathrm{mg} . \mathrm{L}^{-1}$; natural $\mathrm{pH}=7.85 ; \mathrm{T}=19^{\circ} \mathrm{C} ; \mathrm{TOC}=3.1 \mathrm{mg} . \mathrm{L}^{-1}$; left: no radical scavenger, right: $10 \mathrm{mM}$ tert-butanol adding 

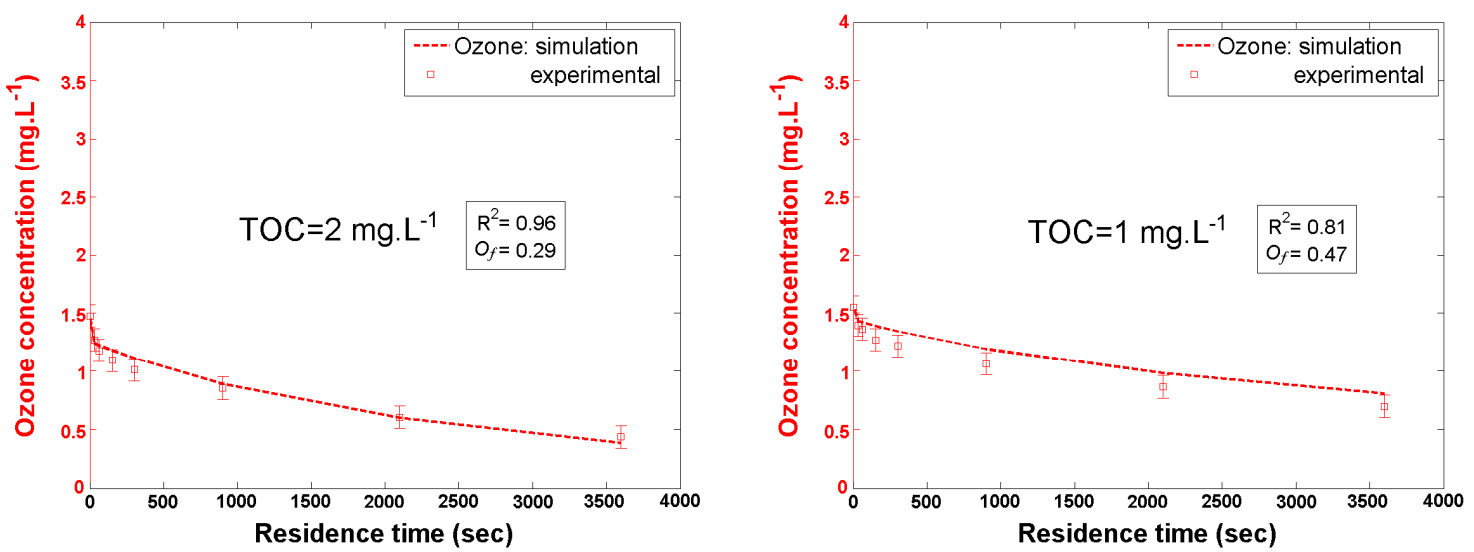

Figure 5. Experimental and simulated concentration profiles, $\{$ Vitré, Winter $\}$ water: $A_{T}=1.02$ meq. $L^{-1}$; small ozone dose $\approx 1.5 \mathrm{mg} . \mathrm{L}^{-1}$; lowered $\mathrm{pH}=6.4 ; \mathrm{T}=20^{\circ} \mathrm{C} ; 10 \mathrm{mM}$ tert-butanol adding; left: $\mathrm{TOC}=2$ $\mathrm{mg} . \mathrm{L}^{-1}$, right: $\mathrm{TOC}=1 \mathrm{mg} . \mathrm{L}^{-1}$ (reached by dilution with ultra pure water, ozonated and deozonated beforehand)

Another illustration of the goodness-of-fit is given in figures 6 and 7 through the comparisons between experimental and simulated concentrations, for ozone and $p$ CBA respectively ( $\{$ Annet-sur-Marne, Summer \} water sample). The complete set of experiments on \{Annet-sur-Marne, Summer\} water sample is presented in these figures, which represent the same 10 experiments. As it can be globally seen on figures 1 to $7, p \mathrm{CBA}$ concentrations are more difficult to model than ozone concentrations. Note on figures 6 and 7 the relative position of the $90^{\text {th }}$ percentile lines with regards to the experimental uncertainty. The modeling results obtained with \{Annet-sur-Marne, Summer\} water sample can be considered as average, with 2 experiments ranked very good, 5 experiments ranked good and 3 ranked mediocre.

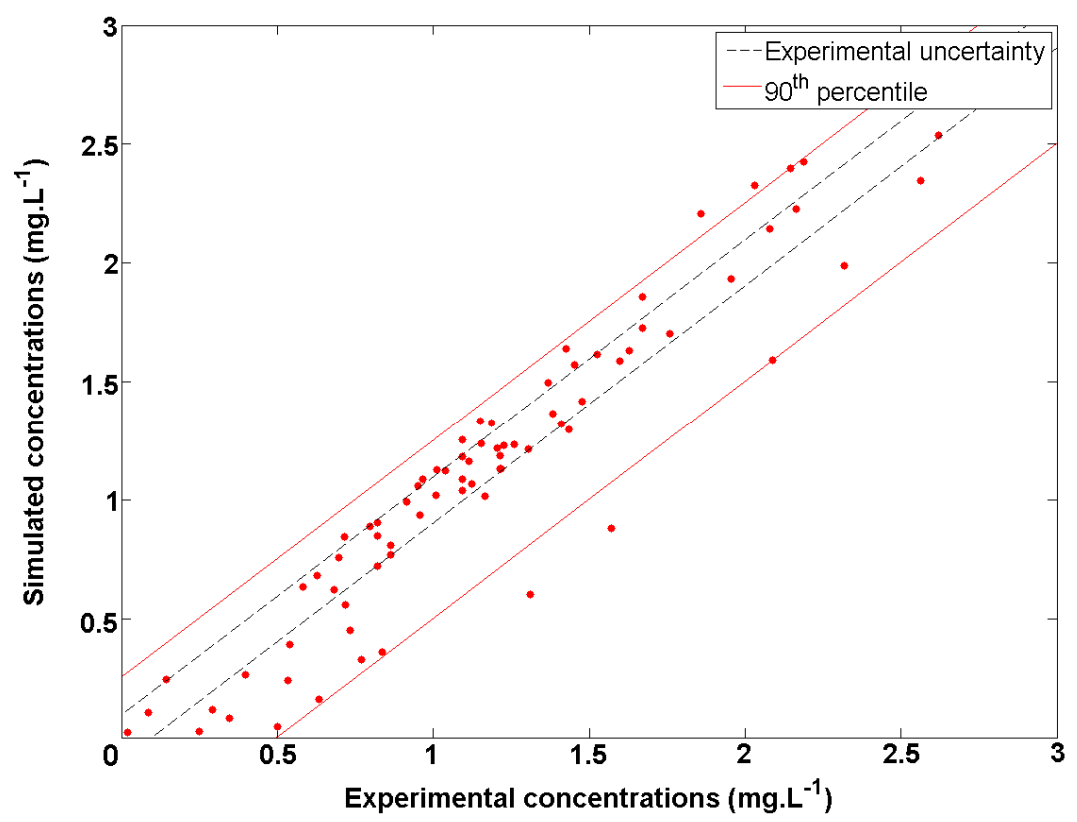

Figure 6. Comparison of experimental and simulated concentration measurements for ozone, \{Annetsur-Marne, Summer\} water sample, 10 experiments 


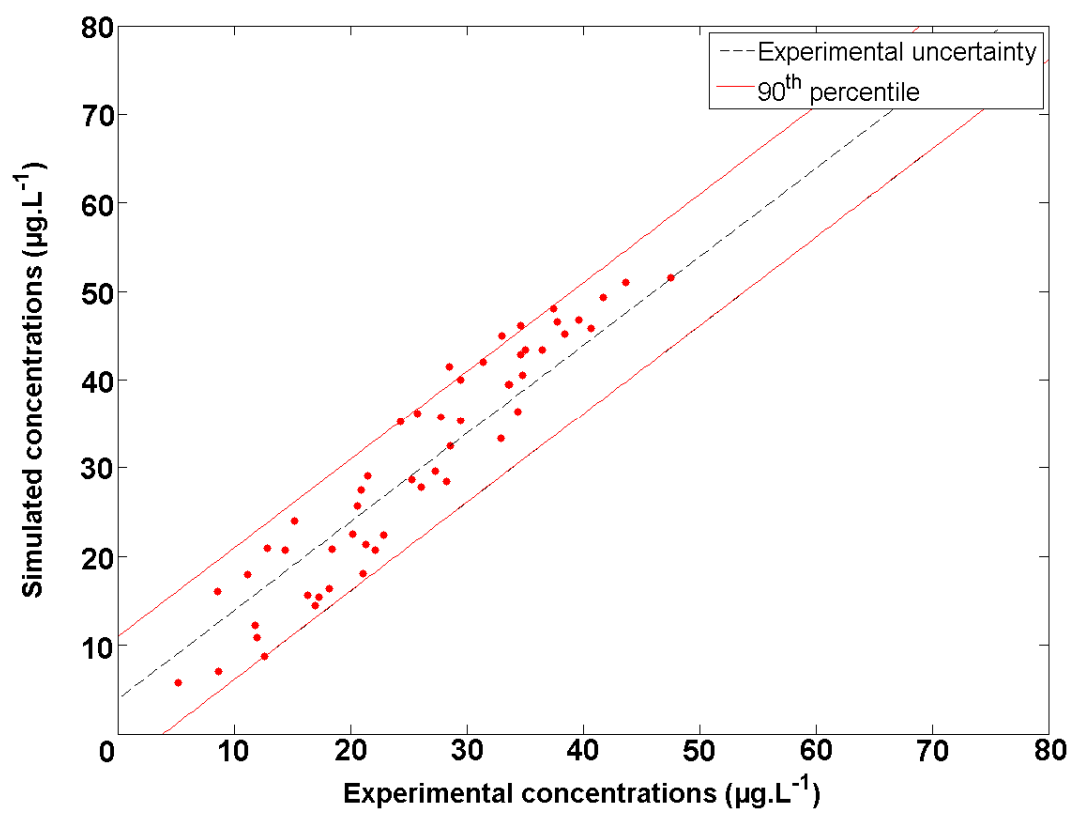

Figure 7. Comparison of experimental and simulated concentration measurements for $p$ CBA, \{Annetsur-Marne, Summer\} water sample, 10 experiments

\subsection{Testing the Model: Summary of Results}

All the experiments were ranked according to the definitions of the quality groups used with the goodness-of-fit measures. The results are gathered in figure 8. Globally, 64\% (7 out of 11) of the water samples have more than two thirds of their experiments which are considered as good or very good; $64 \%$ of the water samples have more than a third of their experiments which are considered as very good. The modeling results were not satisfactory for two water samples: Beaufort, Spring and Trondheim, Spring. For these water samples however, the very good experiments still represented around $25 \%$. 


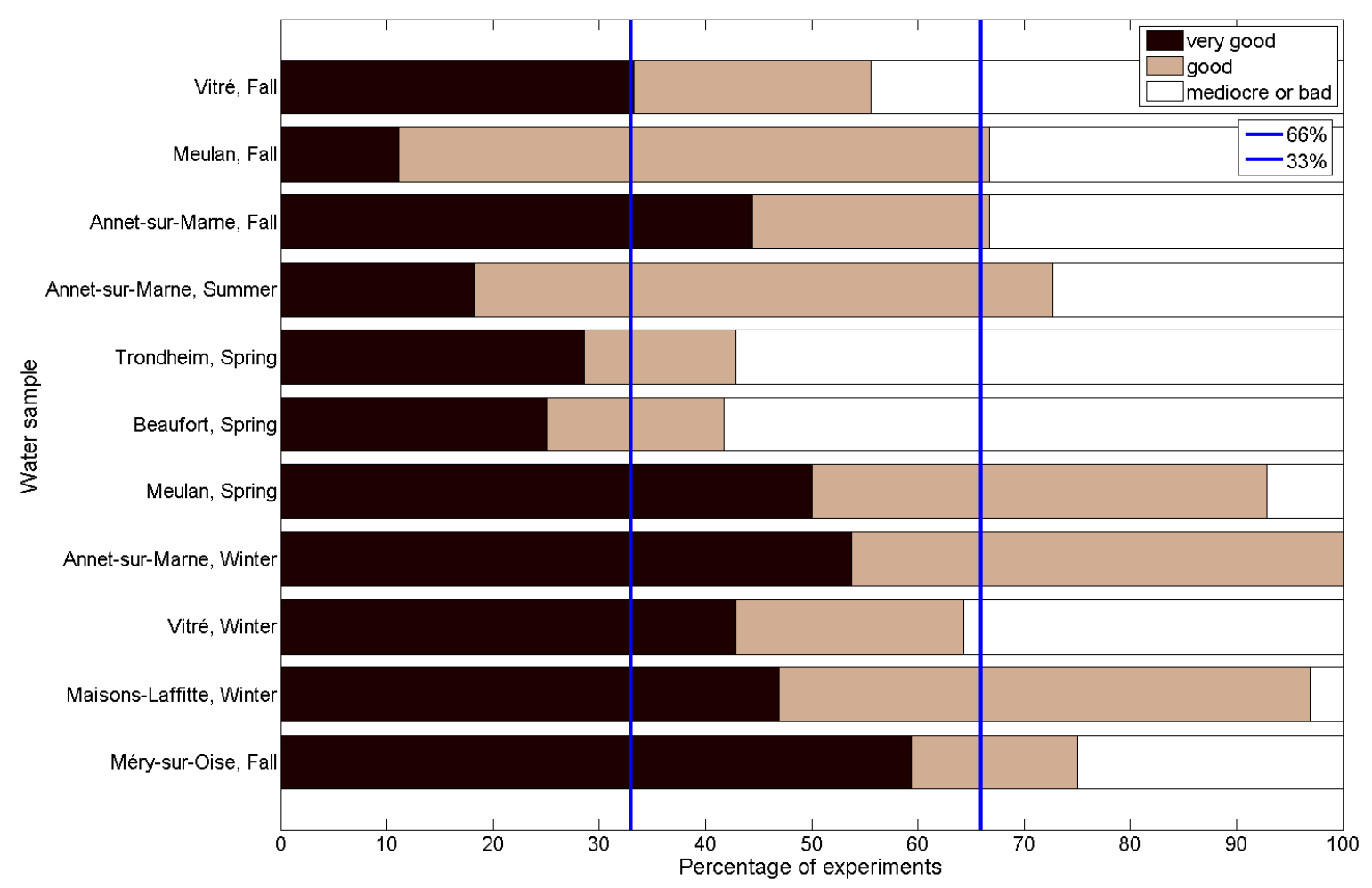

Figure 8. Distribution of the quality of the simulations, all datasets

\section{DISCUSSION}

\subsection{Domain of Validity of the Model}

Results showed that the model is robust and can handle different water characteristics and different experimental conditions. The model is able to take into account all experimental condition changes (reaction time with ozone, ozone dose, $\mathrm{pH}$, temperature, radical scavenger adding and NOM dilution). Moreover, modeling results are satisfactory for $75 \%$ of the experiments.

\subsubsection{Water Quality Characteristics}

The quality of the model predictions is contrasted for two water samples out of eleven: \{Beaufort, Spring $\}$ and $\{$ Trondheim, Spring $\}$. In both cases, ozone concentrations are well predicted while $p$ CBA concentrations are modeled poorly (underprediction). Both samples have high organic content, and at the same time, low inorganic content. The water samples from \{Vitré, Winter and Fall \}, for which more than a third of the experiments were classified as mediocre or bad in figure 8 , have also a large organic/inorganic ratio, to a smaller extent however.

One possible explanation for this limitation lies in a hypothesis of the model. Apart from consumers, initiators and promoters, authors generally consider radical scavengers when defining reactive NOM fractions [5]. In this study however, following the conclusions of [36], scavenger-acting species were regarded as negligible compared to carbonate species. This hypothesis may not hold anymore for water samples such as $\{$ Beaufort, Spring $\}$ and \{Trondheim, Spring\}.Therefore, test simulations were run with a model including a radical-scavenging fraction of NOM. The model was tested with \{Trondheim, Spring\} water, but the results were only slightly improved. Given the gap observed between the 
experimental and simulated points (especially for long reaction times with ozone), it is likely that the stoichiometry (1:1) of the scavenging reaction has to be changed.

Finally, a wide range of water characteristics has been experimentally studied and modeled. If we consider three global indicators for water quality: $\mathrm{pH}, \mathrm{A}_{\mathrm{T}}$ and $\mathrm{TOC}$, experiments have been done at low, medium and high values for the three indicators - including almost all $3^{3}=27$ possible combinations. Considering all the water samples modeled satisfactorily, the following domain of validity can be determined:

$$
\begin{array}{ll}
- & 6 \leq \mathrm{pH} \leq 8 ; \\
- & 1 \mathrm{meq} . \mathrm{L}^{-1} \leq \mathrm{A}_{\mathrm{T}} \leq 6 \mathrm{meq} . \mathrm{L}^{-1} ; \\
- & 0-0.5 \mathrm{mgC} . \mathrm{L}^{-1} \leq \mathrm{TOC} \leq 3.1 \mathrm{mgC} . \mathrm{L}^{-1} .
\end{array}
$$

\subsubsection{Experimental Conditions}

By reviewing the results obtained with the first and the second designs of experiments (discarding the results from \{Beaufort, Spring $\}$ and \{Trondheim, Spring\}), a ranking of the best simulated experiments was established. It was found that some experiments were systematically well predicted while others less accurately.

The best predictions were obtained under following experimental conditions:

- $\quad$ Scavenger adding;

- $\quad$ Scavenger adding with simultaneous $\mathrm{pH}$ drop, temperature drop or NOM dilution;

- $\quad$ large ozone dose with simultaneous pH drop;

- $\quad$ large ozone dose with simultaneous NOM dilution.

Less accurate predictions were obtained for the following experimental conditions:

- $\quad$ large ozone dose;

- $\quad$ simultaneous temperature and $\mathrm{pH}$ drops;

- $\quad$ NOM dilution with simultaneous pH drop.

Experiments for which radical scavengers had been added were very well predicted whatever the other experimental conditions ( $\mathrm{pH}$ drop, temperature drop, NOM dilution). This reflects the fact that predicting concentrations is simple for ozone compared to hydroxyl radicals. Predicting the impact of a change in initial ozone concentration is more difficult with the model as ozone and $p$ CBA concentrations were respectively slightly overpredicted and underpredicted when ozone dose was increased. This mismatch was reduced when $\mathrm{pH}$ was lowered or when NOM was diluted. An explanation relates to the assumption made for calculating the initial hydroxyl radical concentration. Based on typical reported values for the $\mathrm{R}_{\mathrm{ct}}$ in natural water ([13]; [37]), the initial hydroxyl radical concentration was calculated according to: $\left[{ }^{\circ} \mathrm{OH}\right]_{0}=10^{-8}$. $\left[\mathrm{O}_{3}\right]_{0}$. The same $\mathrm{R}_{\mathrm{ct}}$ value of $10^{-8}$ was used to simulate all experimental conditions. It has however been reported that $\mathrm{R}_{\mathrm{ct}}$ changes with $\mathrm{pH}$, temperature and NOM properties [13], but also more recently with ozone dose [38]. Predicting the impact of simultaneous drops in temperature and $\mathrm{pH}$ was also found to be difficult. It is likely that simultaneous temperature and $\mathrm{pH}$ drops would have been better modeled if temperature dependence for $\mathrm{pK}_{\mathrm{A}} \mathrm{s}$ would have been taken into account.

\subsubsection{Seasonal Variations of NOM}

As the kinetics of ozone with NOM may be altered by seasonal variations of the water quality, the seasonal stability of the model has to be determined. This has been done by exploring the robustness of the model calibration: the values of the parameters found with \{Annet-sur-Marne, Winter\} water sample were used to simulate the experiments done with \{Annet-sur-Marne, Summer\} and AAnnet-sur-Marne, Fall \} water samples; the values of the parameters found with \{Meulan, Spring\} and \{Vitré, Winter water samples were used to respectively simulate the experiments done with \{Meulan, Fall $\}$ and $\{$ Vitré, Fall $\}$ water samples. The results are presented in figure 9 and can be compared with the results obtained previously on $\{$ Annet-sur-Marne, Summer and Fall $\} ;$ Meulan, Fall $\}$ and $\{$ Vitré, Fall $\}$ water samples. 


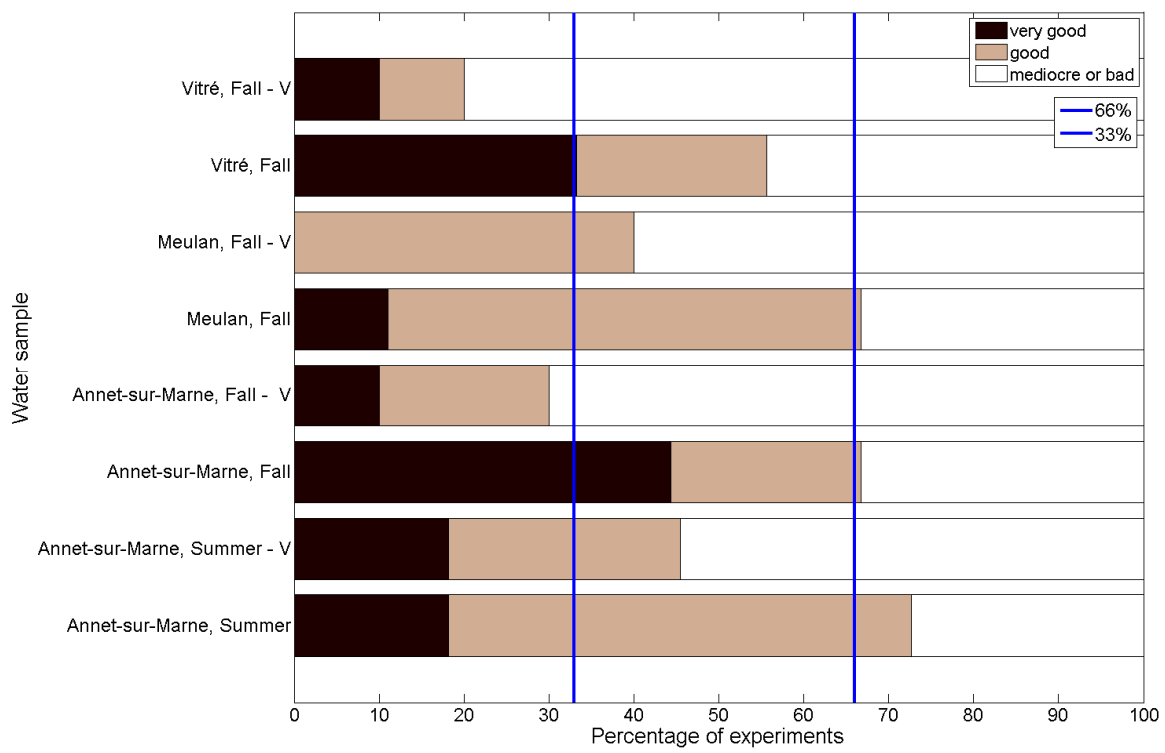

Figure 9. Distribution of the quality of the simulations done when calibrating the model at another season (sample names followed by "V" for "validation"), comparison with a calibration for each water sample

Results show that the quality of the predictions decreases when having calibrated the model at another season. This remark applies however differently to ozone and to $p$ CBA. As illustration, we give in figure 10 the comparison of experimental and simulated concentrations for ozone and $p$ CBA for all the water samples from Annet-sur-Marne, using the model calibrated only on the basis of the experimental results obtained with \{Annet-sur-Marne, Winter $\}$. On one hand, despite scattering of the points, predictions for ozone concentrations are relatively reliable and the model is found to be stable throughout the year. On the other hand, predictions for $p$ CBA are much less accurate, even if the linearity between experimental and simulated data remains high $\left(\mathrm{R}^{2}=0.86\right.$ for \{ Annet-sur-Marne, Summer $\} ; \mathrm{R}^{2}=0.84$ for $\{$ Annet-sur-Marne, Fall $\left.\}\right)$. Note in particular the progressive drift of the results for $p$ CBA concentrations. A similar trend was observed with the water samples from Vitre, and to a smaller extent, with the water samples from Meulan.
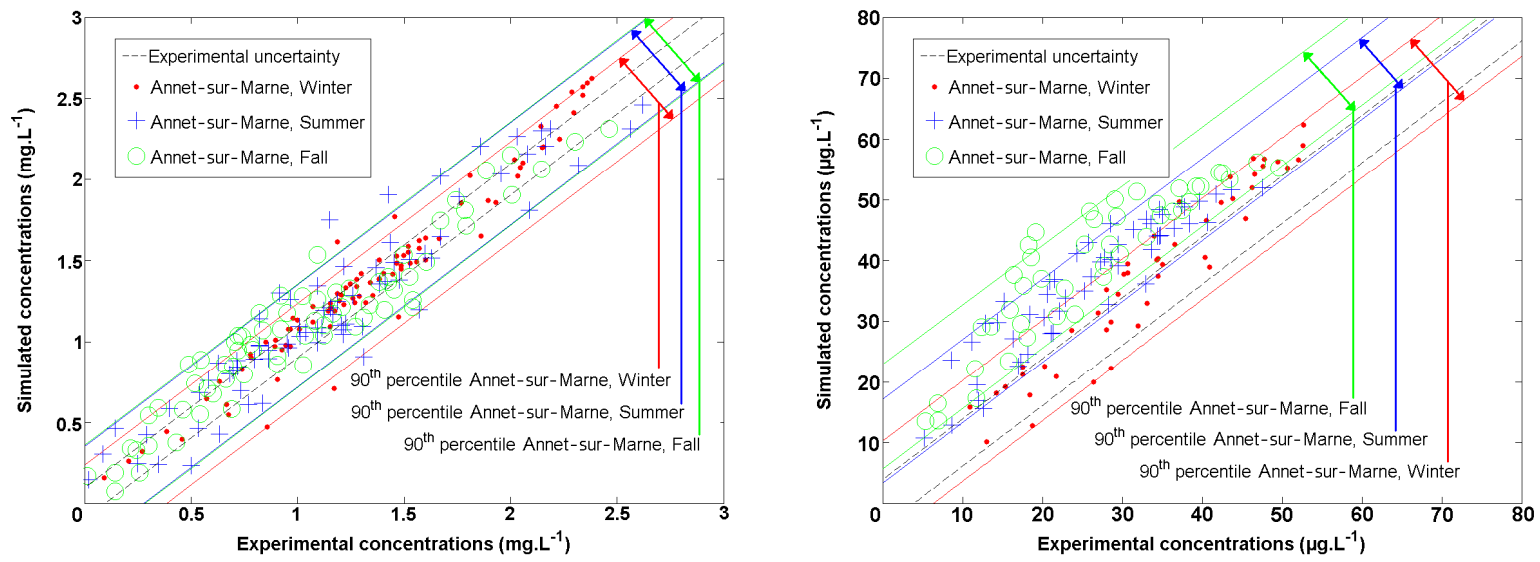

Figure 10. Comparisons of experimental and simulated concentration measurements for Annet-surMarne water samples. Model calibration based on \{Annet-sur-Marne, Winter $\}$ results. Left: ozone; right: $p$ CBA. 


\subsection{Reducing the Data Needed for Calibration: Validation of the Model}

From a practical perspective, doing 10 to 32 experiments to calibrate the proposed model is feasible, still cumbersome and expensive. From a modeling perspective, if all the experimental data are used for calibration, there is no guarantee that the model is able to extrapolate to different experimental conditions.

A methodology, proposed in [21], combines experimental and numerical approaches (i) to reduce the experimental dataset needed for calibrating the model; (ii) and to reduce the number of parameters optimized together. On one hand, the most influent experimental conditions are determined by multiple linear regression analysis; by considering only these influent conditions, the number of calibration experiments is reduced. On the other hand, the most influent model parameters on the objective function are determined by sensitivity analysis; by sequencing the calibration of the parameters according to their sensitivities, the size of the mathematical problem is reduced.

The results of the multiple linear analysis performed on five water samples ( $\{$ Méry-sur-Oise, Fall $\}$; \{Maisons-Laffitte, Winter\}; \{Annet-sur-Marne, Winter\}; \{Meulan, Spring $\}$ and $\{$ Vitré, Winter $\}$ ) show that:

- $\quad$ Experimental ozone concentration is mostly sensitive to $\mathrm{pH}$ and temperature drops;

- $\quad$ Experimental $p$ CBA concentration is mostly sensitive to the adding of radical scavengers.

The results of the sensitivity analysis show that:

- $\quad$ NOM fractions which mainly modify the concentration profiles for ozone and $p \mathrm{CBA}$, are the initiating and consuming fractions;

- $\quad$ Promoting fraction plays a smaller role.

Based on these results, a reduced set of experiments was defined for calibration purposes. Six experiments were selected and used to calibrate the model (see [21]). The remaining experiments were used for validation. We present in figure 11 the results obtained with this reduced calibration procedure. Comparing with previous results (figure 8), it can be concluded that the reduced calibration procedure gives modeling results almost as good as those obtained with much more experimental data.:

- $\quad$ The number of experiments to do at laboratory to calibrate the model can be reduced. Doing the six experiments used in the reduced calibration procedure represents 2 days of lab work;

- $\quad$ The model was validated a posteriori, given that $70 \%$ of the experiments could be predicted satisfactorily by extrapolation ( $80 \%$, when using all the experiments for calibration).

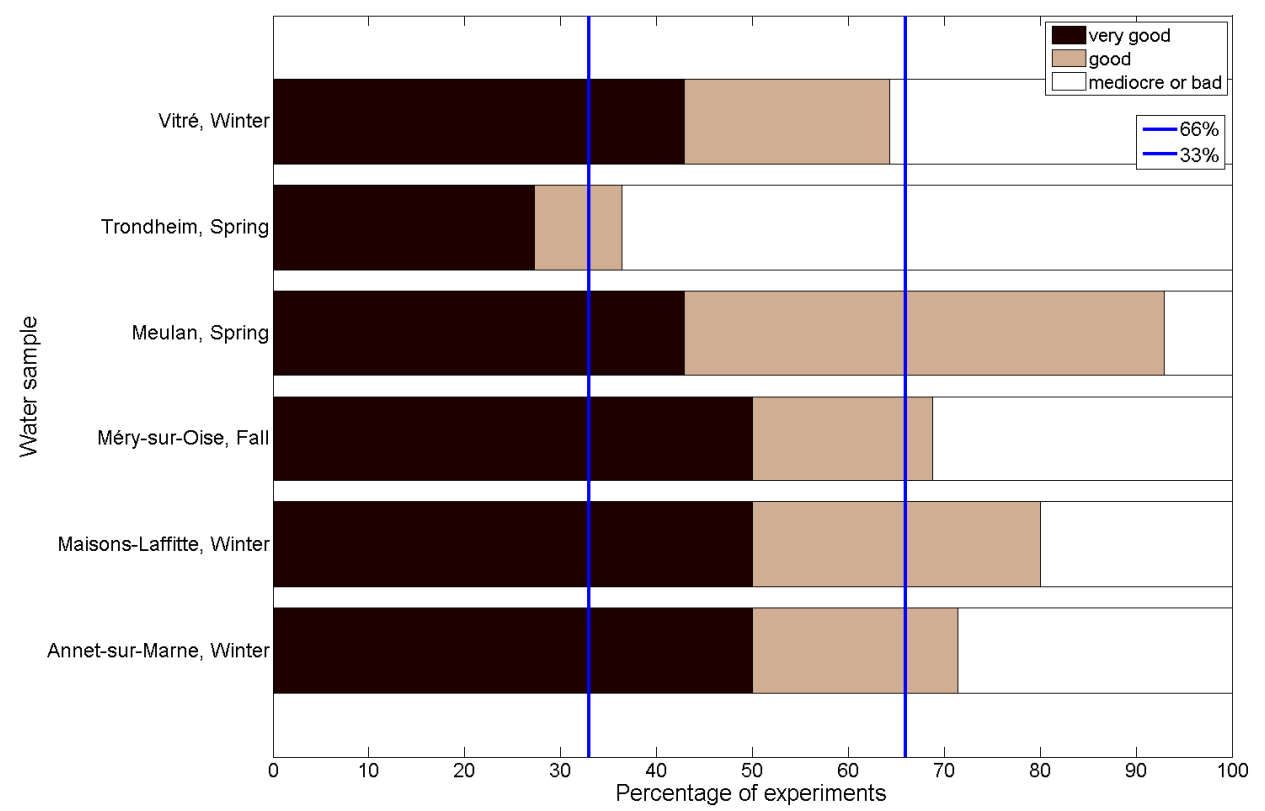

Figure 11. Distribution of the quality of the simulations for 6 water samples, full-dataset validation based on reduced-dataset calibration 


\subsection{Comparison to Other Modeling Studies}

\subsubsection{Amount of Data}

Most authors who have modeled the kinetics of ozone with NOM focused on other aspects of the ozonation process: bromate formation ([39]; [11]), impact of inorganic carbon [17], fate of micropollutants ([40]; [41]), pathogen inactivation [11]. Consequently, little amounts of data can be found in these studies on the kinetics of ozone with NOM.

Studies focusing on the kinetics of ozone with NOM proposed to link the reactivity of natural water to that of NOM isolates. Therefore, those studies ([15]; [16]) focused on a single water source which was then thoroughly studied. In particular, Bezbarua [15] tested a model over a very large experimental dataset. However, the experiments were done with radical scavenger adding $\left(0.5-4.10^{-4} \mathrm{M}\right.$ tert-butanol), whereas $45 \%$ the experiments of this study were done without tert-butanol adding. In addition, no study has, to our knowledge, compared the modeling of ozone and $p$ CBA decompositions on water samples from different resources. The impact of seasonal variations of NOM on the modeling of the kinetics of ozone and hydroxyl radicals with NOM remains unpublished.

\subsubsection{Values of the Parameters}

Numerical tests gave evidence of the non-unicity of the solutions found for the values of the parameters [21]; we shall therefore not discuss in detail the values of the model parameters. It is likely that a high number of combinations for parameter values may lead to similar modeling results. Therefore, conclusions among modeling studies cannot be directly established and physicochemical conclusions should not be drawn. A similar remark was made for biological models (ASMs) [42]. The values of the parameters of the model can be found for each water sample in [21].
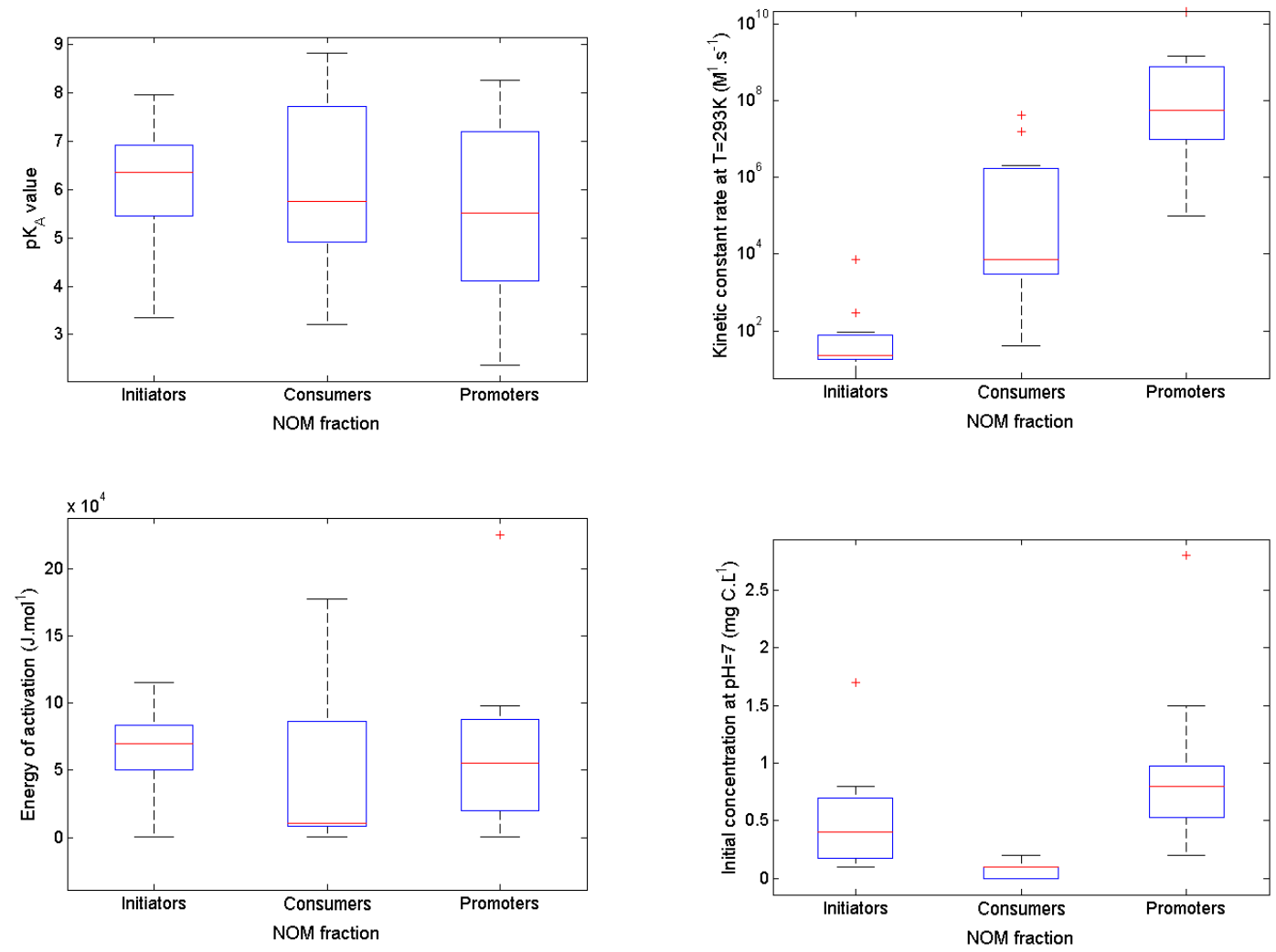

Figure 12. Distribution of the values of the model parameters (among the 11 water samples): $\mathrm{pK}_{\mathrm{A}} \mathrm{S}$, kinetic constant rates, energies of activation, initial concentrations of the different NOM fractions 
The values taken by the model parameters are globally consistent with common kinetic values reported for comparable reactions, as suggested by the boxplots of the $\mathrm{pK}_{\mathrm{A}} \mathrm{s}$, kinetic constant rates, energies of activation and initial concentrations represented in figure 12. It is also interesting to note that, contrary to $\mathrm{pK}_{\mathrm{A}}$ values, which are quite similarly distributed over the NOM fractions, kinetic constant rates and initial concentrations tend to be more dependent on the type of NOM fraction considered: constant rates for initiation tend to be evenly distributed among the 11 water samples and are generally below $100 \mathrm{M}^{-}$ ${ }^{1} \cdot \mathrm{s}^{-1}$, whereas for consumers they mostly range from $10^{4} \mathrm{M}^{-1} \cdot \mathrm{s}^{-1}$ to $10^{6} \mathrm{M}^{-1} \cdot \mathrm{s}^{-1}$ and for promoters from $10^{7} \mathrm{M}^{-1} \cdot \mathrm{s}^{-1}$ to $10^{9} \mathrm{M}^{-1} \cdot \mathrm{s}^{-1}$. Two initial concentrations for promoters were found higher than $1 \mathrm{mg} \mathrm{C} . \mathrm{L}^{-1}$, suggesting that only general conclusions should be drawn from comparisons among parameter values. These high values can be explained by the non-unicity of the solutions found and by the less important sensitivity of the model outputs towards the promoting fraction.

\section{CONCLUSION}

The proposed model is able to adequately reproduce changes in reaction time with ozone, ozone dose, $\mathrm{pH}$, temperature, radical scavenger adding (tert-butanol), and NOM dilution (75\% of the experiments were modeled satisfactorily). This model was validated on a very large experimental dataset comprising more than 1200 and 900 concentration measurements for ozone and $p$ CBA, respectively (11 water samples from 7 water resources). Generally, ozone concentrations were better modeled than $p$ CBA concentrations. Considering all the water samples modeled satisfactorily, the following domain of validity can be determined:

$$
\begin{array}{ll}
- & 6 \leq \mathrm{pH} \leq 8 ; \\
- & 1 \mathrm{meq} . \mathrm{L}^{-1} \leq \mathrm{A}_{\mathrm{T}} \leq 6 \mathrm{meq} . \mathrm{L}^{-1} ; \\
\text { - } & 0-0.5 \mathrm{mgC} . \mathrm{L}^{-1} \leq \mathrm{TOC} \leq 3.1 \mathrm{mgC} . \mathrm{L}^{-1} .
\end{array}
$$

Seasonal comparisons showed that the quality of the predictions decreases when having calibrated the model at another season. This remark applies however differently to ozone and to $p$ CBA: predictions for ozone concentrations are reliable throughout the year, whereas predictions for $p \mathrm{CBA}$ are progressively drifted.

The experimental dataset for calibration could be reduced to 6 experiments, out of 32, without excessive loss in quality over the whole validity domain. For a group of five water samples, this alternate calibration procedure gave good results: $70 \%$ of the experiments were modeled satisfactorily; when using all the experiments for calibration, $80 \%$ of the experiments were modeled satisfactorily. In order to broaden the results of this study, following modeling and experimental prospects can be formulated:

- $\quad$ It was not possible to adequately simulate waters with high $\mathrm{TOC} / \mathrm{A}_{\mathrm{T}}$ ratios, most likely because of the necessity for such matrices to consider a model for radical scavenging by NOM. First trials have been unsuccessful in incorporating NOM scavenging. Future work shall deal with this issue;

- $\quad$ A procedure to systematically minimize the number of experiments to be considered for calibration purposes may be developed. So far, six experiments have been chosen for a simplified calibration. Was this choice optimal? Could the number of experiments considered for calibration be further reduced?

The proposed model, together with a mechanistic model for the formation of bromate, has been implemented successfully at full-scale on an industrial ozonation unit [43]. Results showed that such an approach is sound and may be used for decision-support tools, in particular to address the trade-off between disinfection and by-product formation.

\section{ACKNOWLEDGMENTS.}


This research is partially supported by the European Commission in frame of the integrated project TECHNEAU. We thank Ms. Delphine Bourdin and Mr. Huy-Hoang Pham for their technical assistance. We thank Dr. N.J. Maximilian Macaluso for refining the English in the manuscript and the referees for their helpful comments.

\section{REFERENCES.}

[1] U. von Gunten, U. Pinkernell, Ozonation of bromide-containing drinking waters: a delicate balance between disinfection and bromate formation, Water Sci. Technol. 41 (7) (2010) 53-59.

[2] P. Roccaro, G. Mancini, F. G. A. Vagliasindi, Water intended for human consumption - Part I: Compliance with European water quality standards, Desalination 176 (1) (2005) 1-11.

[3] R. P. Schwarzenbach, B. I. Escher, K. Fenner, T. B. Hofstetter, C. A. Johnson, U. von Gunten, B. Wehrli, The Challenge of Micropollutants in Aquatic Systems, Science 313 (5790) (2006) 1072-1077.

[4] E. H. Goslan, D. A. Fearing, J. Banks, D. Wilson, P. Hills, A. T. Campbell, S. A. Parsons, Seasonal variations in the disinfection by-product precursor profile of a reservoir water, J. Water Supply: Res. Technol. - AQUA 51 (2002) 475- 482.

[5] J. Staehelin, J. Hoigné, Decomposition of Ozone in Water in the Presence of Organic Solutes Acting as Promoters and Inhibitors of Radical Chain Reactions, Environ. Sci. Technol. 19 (12) (1985) 12061213.

[6] J. A. Leenheer, J.-P. Croué, Characterizing Aquatic Dissolved Organic Matter, Environ. Sci. Technol. 37 (1) (2003) 19A-26A.

[7] U. von Gunten, Ozonation of drinking water: Part I. Oxidation kinetics and product formationReview, Water Research 37 (7) (2003) 1443-1467.

[8] M. D. Gurol, P. C. Singer, Kinetics of Ozone decomposition: A Dynamic Approach, Environ. Sci. Technol. 16 (7) (1982) 377-383.

[9] M. Roustan, H. Debellefontaine, Z. Do-Quang, J.-P. Duguet, Development of a Method for the Determination of Ozone Demand of a Water, Ozone: Sci. Eng. 20 (6) (1998) 513-520.

[10] M. S. Elovitz, U. von Gunten, Hydroxyl Radical/Ozone Ratios during Ozonation Processes. I. The $\mathrm{R}_{\mathrm{ct}}$ Concept, Ozone: Sci. Eng. 21 (3) (1999) 239-260.

[11] J.-H. Kim, M. S. Elovitz, U. von Gunten, H. M. Shukairy, B. J. Mariñas, Modeling Cryptosporidium parvum oocyst inactivation and bromate in a flow-through ozone contactor treating natural water, Water Research 41 (2) (2007) 467-475.

[12] S. G. Zimmermann, M. Wittenwiler, J. Hollender, M. Krauss, C. Ort, H. Siegrist, U. von Gunten, Kinetic assessment and modeling of an ozonation step for full-scale municipal wastewater treatment: micropollutant oxidation, by-product formation and disinfection, Water Research 45 (2) (2011) 605617. 
[13] M. S. Elovitz, U. von Gunten, H. P. Kaiser, Hydroxyl Radical/Ozone Ratios During Ozonation Processes. II. The Effect of Temperature, pH, Alkalinity, and DOM Properties, Ozone: Sci. Eng. 22 (2) (2000) 123-150.

[14] S. Vincent, A. Kotbi, B. Barbeau, Predicting Hydroxyl Radical Activity and Trace Contaminants Removal in Ozonated Water, Ozone: Sci. Eng. 32 (4) (2010) 244-251.

[15] B. K. Bezbarua, Modeling Reactions of Ozone with NOM. Ph.D. Dissertation, University of Massachusetts Amherst, USA, 1997.

[16] P. Westerhoff, R. Song, G. Amy, R. Minear, Application of Ozone Decomposition Models, Ozone: Sci. Eng. 19 (1) (1997) 55-73.

[17] J. L. Acero, U. von Gunten, Influence of Carbonate on the Ozone/Hydrogen Peroxide Based Advanced Oxidation Process for Drinking Water Treatment, Ozone: Sci. Eng. 22 (3) (2000) 305-328.

[18] J. A. Leenheer, T. I. Noyes, A Filtration and Column-Adsorption System for Onsite Concentration and Fractionation of Organic Substances from Large Volumes of Water, U.S. Geological Survey Water Supply Paper 2230, U.S. Geological Water Survey, Alexandria, VA, 1984.

[19] P. Mandel, D. Wolbert, P. Roche, H.-H. Pham, P. Bréant, A modelling procedure for on-site ozonation steps in potable water treatment, Water Sci. Technol.: Water Supply 9 (4) (2009) 459-467.

[20] U. von Gunten, A. Driedger, H. Gallard, E. Sahli, By-products formation during drinking water disinfection: a tool to assess disinfection efficiency?, Water Research 35 (8) (2001) 2095-2099.

[21] P. Mandel, Modelling Ozonation Processes for Disinfection By-Product Control in Potable Water Treatment: From Laboratory to Industrial Units, Ph.D. Dissertation, ENSC-R, France, 2010. Available at: http://tel.archivesouvertes.fr/docs/00/56/47/67/PDF/Modelling Ozonation Processes MANDEL.pdf

[22] T. Mizuno, H. Tsuno, H. Yamada, Development of Ozone Self-Decomposition Model for Engineering Design, Ozone: Sci. Eng. 29 (1) (2007) 55-63.

[23] H.Tomiyasu, H. Fukutomi, G. Gordon, Kinetics and Mechanism of Ozone Decomposition in Basic Aqueous Solution, Inorg. Chem. 24 (19) (1985) 2962-2966.

[24] J. Staehelin, J. Hoigné, Decomposition of ozone in water: Rate of Initiation by Hydroxide Ions and Hydrogen Peroxide, Environ. Sci. Technol. 16 (10) (1982) 676-681.

[25] H. Taube, W. C. Bray, Chain Reactions in Aqueous Solutions Containing Ozone, Hydrogen Peroxide and Acid, JACS 62 (12) (1940) 3357-3373.

[26] R. E. Bühler, J. Staehelin, J. Hoigné, Ozone Decomposition in Water Studied by Pulse Radiolysis. 1. $\mathrm{HO}_{2} / \mathrm{O}_{2}{ }^{-}$and $\mathrm{HO}_{3} / \mathrm{O}_{3}{ }^{-}$as Intermediates, J. Phys. Chem. 88 (12) (1984) 2560-2564.

[27] K. Chelkowska, D. Grasso, I. Fabian, G. Gordon, Numerical Simulations of Aqueous Ozone Decomposition, Ozone: Sci. Eng. 14 (1) (1992) 33-49. 
[28] P. C. Farhataziz, A. B. Ross, Selective Specific Rates of Reactions of Transients from Water in Aqueous Solutions, National Bureau of Standards: Washington, DC, Natl. Stand. Ref. Data Ser. (U.S., Natl. Bur. Stand., 1977) No. 59.

[29] J. Staehelin, R. E. Bühler, J. Hoigné, Ozone Decomposition in Water Studied by Pulse Radiolysis. 2. $\mathrm{OH}$ and $\mathrm{HO}_{4}$ as Chain Intermediates, J. Phys. Chem. 88 (24) (1984) 5999-6004.

[30] G. V. Buxton, C. L. Greenstock, W. P. Helman, A. B. Ross, Critical Review of Rate Constants for Reactions of Hydrated Electrons, Hydrogen Atoms and Hydroxyl Radicals in Aqueous Solution, J. Phys. Chem. Ref. Data 17 (2) (1988) 513-886.

[31] K. Chelkowska, D. Grasso, I. Fábián, G. Gordon, Mechanistic Comparison of Residual Ozone Decomposition, Proceedings of the IOA Conference, Shreveport, (1990) 427-437.

[32] R. C. Weast, S. M. Selby, CRC Handbook of Chemistry and Physics, $48^{\text {th }}$ Edition, Cleveland, OH: The Chemical Rubber Co. (1967).

[33] S.-N. Chen, M. Z. Hoffman, Effect of $\mathrm{pH}$ on the reactivity of the carbonate radical in aqueous solution, Radiat. Res. 62 (1) (1975) 18-27.

[34] J. Hoigné, H. Bader, Rate Constants of Reactions with Ozone with Organic and Inorganic Compounds in Water-II Dissociating Organic Compounds, Water Research 17 (2) (1983)185-194.

[35] C. D. Schunn, D. Wallach, Evaluating goodness-of-fit in comparison of models to data, in W. Tack (Ed.), Psychologie der Kognition: Reden and Vorträge anlässlich der Emeritierung von Werner Tack. Saarbrüken, Germany: University of Saarland Press (2005) 115-154.

[36] B. Savary, Influence des caractéristiques d'une eau naturelle sur la formation des ions bromates au cours de l'ozonation: Observations-Prévisions-Simulations dans un réacteur diphasique du type colonne à bulles, Ph.D. Dissertation ENSC-R, France, 2002.

[37] M. A. Buffle, J. Schumacher, E. Salhi, M. Jekel, U. von Gunten, Measurement of the Initial Phase of Ozone Decomposition in Water and Wastewater by Means of a Continuous Quench Flow System: Application to Disinfection and Pharmaceutical Oxidation, Water Research 40 (9) (2006) 1884-1894.

[38] M. A. Buffle, J. Schumacher, S. Meylan, M. Jekel, U. von Gunten, Ozonation and Advanced Oxidation of Wastewater: Effect of $\mathrm{O}_{3}$ Dose, $\mathrm{pH}$, DOM and HO•-scavengers on Ozone Decomposition and HO• Generation, Ozone: Sci. Eng. 28 (4) (2006) 247-259.

[39] P. Westerhoff, R. Song, G. Amy, R. Minear, Numerical Kinetic Models for Bromide Oxidation to Bromine and Bromate, Water Research 32 (5) (1998) 1687-1699.

[40] A. Laplanche, M. T. Orta de Velasquez, V. Boisdon, N. Martin, G. Martin, Modelisation Of Micropollutant Removal In Drinking Water Treatment By Ozonation Or Advanced Oxidation Processes $\left(\mathrm{O}_{3} / \mathrm{H}_{2} \mathrm{O}_{2}\right)$, Ozone: Sci. Eng. 17 (1) (1995) 97-117.

[41] F. J. Beltrán, M. González, B. Acedo, F. J. Rivas, Kinetic modelling of aqueous atrazine ozonation processes in a continuous flow bubble contactor, J. Hazardous Materials 80 (1-3) (2000) 789-206. 
[42] U. Jeppsson, Modelling Aspects of Wastewater Treatment Processes, Ph.D. Dissertation, Lund University, Sweden, 1996. Available at: http://www.iea.lth.se/ ielulf/publications/phd-thesis/PhDthesis.pdf

[43] P. Mandel, M. Maurel, C. Lemoine, P. Roche, D. Wolbert, How Bromate and Ozone Concentrations can be Modeled at Full Scale based on Lab-Scale Experiments - A Case study, Ozone: Sci. Eng. 34 (4) (2012) 280-292. 